\title{
Managing Innovation Clusters: A Network Approach
}

\author{
Giselle Camille Rampersad ${ }^{1}$ \\ ${ }^{1}$ Flinders University, South Australia \\ Correspondence: Dr. Giselle Camille Rampersad, Senior Lecturer in Innovation and Entrepreneurship, Flinders \\ University, Sturt Road, Bedford Park 5042, South Australia. E-mail: giselle.rampersad@flinders.edu.au \\ Received: June 16, 2015 \\ Accepted: July 13, 2015 \\ Online Published: August 5, 2015 \\ doi:10.5430/jms.v6n3p9 \\ URL: http://dx.doi.org/10.5430/jms.v6n3p9
}

\begin{abstract}
Innovation clusters have attracted increased investment worldwide to strengthen regional innovation. However, these clusters have suffered from high failure rates. This trend is not surprising as the existing literature places an inadequate focus on monitoring the effectiveness of such clusters and developing appropriate strategies to boost their success. This paper investigates approaches for effectively managing innovation clusters using a live Australian case study of the Tonsley innovation cluster, an ambitious, integral solution for economic renewal from a declining traditional manufacturing economy towards advanced manufacturing. Extending network management theory, the study contributes to our understanding of important elements in the formation of innovation clusters and its underlying networks; the management and orchestration of key stakeholders; and the performance monitoring towards achievement of anticipated outcomes. It offers important strategic implications for government, university and industry leaders in effectively managing innovation clusters.
\end{abstract}

Keywords: innovation cluster, innovation networks, regional strategic networks, network management, networks, innovation

\section{Introduction}

Innovation is critical for wealth creation and competitiveness of nations and regions (Patel, Sooknanan, Rampersad, \& Munkkur, 2012; Rampersad \& Troshani, 2013). Consequently, innovation clusters have attracted increased worldwide attention in boosting regional innovation and economic development. Defined as "a concentration of 'inter-dependent' firms within the same or adjacent industrial sectors in a small geographic area" (Isaksen \& Hauge, 2002, p. 14) clusters are usually characterised by proximity, networks and specialization (Saxenian, 1994). While the term, innovation cluster, has long featured in the literature (Dicken \& Malmberg, 2001), other terms have more recently been used interchangeably with it, including precincts, hubs, ecosystems or science parks (Clarysse, Wright, Brunnel, \& Mahajan, 2014; Narayanan, Yang, \& Zahra, 2009). The term, innovation network has also emerged to refer to a group of organizations including firms, government agencies and universities working together to achieve shared technological goals (Möller \& Rajala, 2007; Rampersad, Quester, \& Troshani, 2010b). Some innovation networks may span geographic boundaries, yet clusters can be seen as one form of innovation network that includes co-located organizations.

While Silicon Valley has been the most iconic benchmark in recent times, innovation clusters have enjoyed global appeal for decades (Freeman, 1995): for instance, the so-called Silicon Valley of the East, Hsinchu Science Park in Taiwan established in 1980 (Chyi, Lai, \& Liu, 2013). The literature has predominantly featured high-tech clusters, generally in North America (e.g. Route 128 in Boston for biotechnology or the Research Triangle in North Carolina for life science and medical technology) and Europe (e.g. Silicon Fen in Cambridge for software electronics and biotechnology; and photonics clusters in West Midlands, UK and OPTEC in Germany) (Iammarino \& McCann, 2006; Manning, 2013; Saxenian, 1994). More recently, attention has turned to the new 'Silicon Valleys' of knowledge service clusters around software services in the Indian cities of Bangalore, Chennai and Pune; and to R\&D services in locations such as Beijing, Sao Paolo, Moscow and Bucharest (Manning, 2013). Innovation clusters have been recognised for their importance in contributing to economic development through job creation, access to resources, and increased speed of product development (Clarysse et al., 2014; Garrett-Jones, 2004; Iammarino \& McCann, 2006).

Despite its benefits, some innovation clusters have been perceived as failures. Massey, Qintas, and Wield (2004) 
argue that these clusters have sometimes been seen as 'high-tech fantasies' with public finances channelled to promote private wealth of firms and individuals. Additionally, this public investment can sometimes even be seen as actually reducing and substituting private investment through a phenomenon that is now termed 'crowding out' (Cumming \& MacIntosh, 2006). In a similar vein, Bercovitz and Feldman (2011) conclude that there is no benefit in co-location within teams. Sorenson, Rivkin, and Fleming (2006), in contrast, argue that innovation clusters are beneficial for those involved in the development of complex technologies where face-to-face communication with collaborators may be useful. Despite these contradictory findings, there is consensus in the literature that geography alone will not guarantee success and that the primary reason for failure is the lack of sufficient collaboration and linkages between players that underpin these clusters (Boschma, 2005; Giuliani, 2013; Leydesdorff \& Etzkowitz, 1996; Tallman \& Phene, 2007). Furthermore, the failure of these clusters can also be due to insufficient performance monitoring towards desirable innovation outcomes. The problem in monitoring innovation cluster performance originates from the complexity of stakeholders involved in the innovation process and the variety of their objectives from research and education in universities to profit maximization in firms (Ács, Autio, \& Szerb, 2014). These different objectives can make performance evaluation of innovation clusters difficult if it conflicts with organizational performance metrics. For instance, a study based on the government-led cooperative research centre (CRC) program in Australia focused on the challenges for government researchers in reconciling the demands between reward systems in academia focused on 'discovery' while confronted with the need to focus on 'application' when collaborating with industry (Garrett-Jones, Turpin, Burns, \& Diment, 2005).

In light of the variety of stakeholders involved, the research question of this study is: How can innovation clusters be effectively managed, using a network approach? This is important given the changing face of manufacturing internationally as countries attempt to transition from low-cost traditional manufacturing to more sophisticated high value-add advanced manufacturing. In Australia, for instance, with relatively high labour costs and a shrinking traditional manufacturing sector, innovation networks are seen as an important solution in this transformation towards high value add products and services. The departure of Mitsubishi and more recently, Holden and Ford from Australia, involved not only a significant loss of jobs but the almost complete removal of an industry sector. In addressing this question, the study is based on a case study of the AUS\$1.5billion Tonsley innovation cluster in Australia which involves key stakeholders from government, university and industry.

'The Tonsley Redevelopment Project in Adelaide is arguably the most ambitious urban renewal initiative in Australia today. Tonsley is viewed as an integral investment in the future of Adelaide ensuring that it is more resilient in the face of high cost operating environments for industry, finite natural resources, demographic shifts, and competing value systems while enabling new systems of representation, new modes of communication, and potential new forms of capital.' (Antcliff \& Kumic, 2013, p. 1)

Given that the Tonsley Redevelopment project is live, it serves as an ideal pilot for future renewal programs as economies undergo transition from traditional manufacturing towards the development of advanced products and services. The study will integrate the network and the innovation cluster streams towards examining this case to determine how innovation clusters can be effectively managed through the formation of underlying networks, cluster management and performance evaluation. It will provide useful implications to a range of stakeholders involved in innovation. This includes cluster managers, policy makers, industry liaisons, industry managers, technology transfer specialists, commercialisation managers, communication specialists, community engagement officers and product development managers.

\section{Theoretical Background}

The central importance of innovation clusters have long been recognised and featured in the literature (Leydesdorff \& Etzkowitz, 1996; Marshall, 1920; Turpin \& Garrett-Jones, 1997). For instance, Boggs and Rantisi (2003) examine the concept of relational-turn which pertains to actors, their attributes and their economic impact. Similarly, Dicken and Malmberg (2001) examine the concept of the firm-territory nexus which is based on the premise that firms are networks embedded within broader inter-organizational networks within an industrial territory. They explore the notion of bounded systems of governance, whereby, governed spaces have been able to attract investment, firms and increase bargaining power and competitiveness. They also note the complexity of governance within these broader networks and call for a greater focus on analysing interactions for governance within innovation clusters.

Furthermore, the notion of innovation clusters or otherwise termed innovation networks, a form of strategic network, have also attracted the attention of business researchers (Cantù, 2010; Corsaro, Cantù, \& Tunisini, 2012; Nicholson, Tsagdis, \& Brennan, 2013). These complex, hybrid, strategic networks have also recently been the subject of an emerging theory on network management (Dhanaraj \& Parkhe, 2006; Ford, Håkansson, Snehota, \& Gadde, 2002; 
Jacobides, Knudsen, \& Augier, 2006; Möller \& Rajala, 2007; Rampersad et al., 2010b; Teece, 1986). Surrounding this emergence, has been an ongoing debate among network researchers about whether networks can (and indeed should) be managed and the degree to which they are open to similar 'orchestration'. At the heart of the debate is what is the scope of a network, what are its boundaries and from whose perspective is it determined (Möller \& Rajala, 2007). Traditional network researchers view networks as a boundaryless group of organisations and associated relationships and therefore impossible to manage as no one owns or controls it (Ford et al., 2002; Hakansson, 1982). In this view, each organisation in the network is autonomous, with its own agenda and priorities and collaborative partnerships that may include international relationships. More recently, there has been a growing focus on value networks, otherwise termed strategic or issue-based networks comprising a set group of organisations working together to achieve a specific outcome. These are seen as more tractable to manage (Möller \& Rajala, 2007). Innovation networks are thus a type of value network (Möller \& Rajala, 2007). They focus on specific priority areas or issues, around which select organisations can coalesce. For example, the Tonsley precinct focuses on four key areas of specialisation upon which innovation networks can be focused: clean technology; green buildings; medical devices and assistive technologies; and mining and resources (DMITRE, 2012). Managing such networks are critical to ensuring that innovation outcomes are achieved.

Some authors have begun to investigate network management (NM) but further research is necessary. Dhanaraj and Parkhe (2006) provide a framework for managing innovation networks and for understanding how different management processes contribute to innovation outcomes. Their main contribution is the understanding that knowledge mobility, innovation appropriability and network stability are critical to successful innovation. They do not, however, assess the contribution of NM to network outcomes from the perspectives of the variety of network actors, and overlook vital relational dimensions that assist in NM. This paper builds on and extends NM theory. Primarily, it provides deeper insights into outcomes from the perspectives of a range of organisations operating in networks, including firms, government and university stakeholders, taking into account the knowledge creation and innovation appropriation. Additionally, the paper incorporates relational dimensions of network governance within NM theory.

\subsection{Formation of Underlying Partnerships}

Increasingly, the relational view is emerging for its importance in innovation networks (Fradley et al. 2012; Rampersad et al. 2012). Garrett-Jones et al. (2005) investigated the Australian CRC program which is a form of voluntary industry-university research network or value network. Although bound by contractual agreements and having a CEO and governing boards, few feasible sanctions exist for non-performance or withdrawal from the joint endeavour. Mutual trust and personal or group reputations hold the network together. In his investigation of how university and government researchers gauged the benefits and costs of working together, specific forms of governance were less important than the collaborative ethos. Any substantial transaction costs in managing the networks (double reporting or irrelevant performance indicators) were viewed as strongly negative to the collaboration and to the net value of participating. Relationships were key to effective governance of the network. The importance of relational dimensions in NM resonates with the work of other NM researchers (Ford et al., 2002; Rampersad, Quester, \& Troshani, 2010a; Wilkinson, Ritter, \& Johnston, 2004).

Leven, Holmstrom, and Mathiassen (2013) argue that the network orchestrator (or hub) can build awareness of existing member capabilities to inspire collaboration among existing members and to attract new members. Giuliani (2013) investigated how status, capability and cohesion within clusters promote their success. It is therefore important for cluster participants to articulate their reputation in their respective fields, their current areas of capability and their areas of need to foster future cohesion involving reciprocity and complementarity in the creation of value chains across desirable areas of specialisation in these clusters. This can be fostered through a mix of formal collaboration tools (including official capability reports or brochures outlining strengths and key priorities for collaboration, websites, memorandum of understandings and agreements) and informal ones (such as meetings, networking events and communities of practice) that would benefit from the close proximity inherent in clusters.

\subsection{Network Orchestration}

Management of innovation networks is radically different from traditional management within organisations because of the high level of autonomy of all the actors. Management is essentially the 'orchestration' of independent actors. The coordinating authority may range from a single individual assisted by administrative staff to a steering committee comprising the heads of each participating organisation in the innovation network (Rampersad et al., 2010b). Dhanaraj and Parkhe (2006) adopt a structural view of network design. They argue that network design considerations include membership, structure and position of the orchestrator. Membership includes numbers, as well 
as the variety of network actors and their capabilities. The orchestrator notes the density (number of ties in the network) and autonomy (ability to act without being controlled by the network), and is able to alter density by injecting new relationships. Autonomy too is a reflection of the orchestrator(s) policies and attitudes.

Dhanaraj and Parkhe (2006) also focus on three aspects of network management or orchestration: 1. managing knowledge mobility (facilitating knowledge sharing and socialisation through various means, creating a common identity); 2. managing innovation appropriability (equitable distribution or ownership in a clear and consistent manner); and 3. managing network stability (enhancing network reputation, managing expectations and increasing the understanding of capabilities of members).

\subsection{Network Outcomes: A Multi-perspective Network Approach}

Perkmann et al. (2013) discuss the challenges of measuring innovation outcomes given the variety of stakeholders involved. For any innovation network to be sustainable, its management must incorporate metrics that all participating organisations value. Firms are generally geared towards sales, productivity, the recruitment of skilled staff and the development of new products and services (Chyi et al., 2013). Universities are generally motivated by research outcomes surrounding peer evaluation, including publications, citations and research grant income; teaching outcomes and the employability of their graduates; or commercialisation outcomes, including R\&D contract income, the number of startups and patents, the latter two often being shared objectives with government or even firms (Perkmann et al., 2013; Rampersad, 2015). In comparison, governments may see value in return on investment, meeting employment targets, industry attraction, capacity building and patents, the latter being the key indicator used for inter-country comparisons about innovativeness (WEForum, 2014). For convenience, patents have been used as a measure of value creation in a limited manner (Cowan \& Zinovyeva, 2013). This measure has been widely criticised, however, as it fails to capture other forms of innovation, such as service innovation that may not be patentable, and even some new products not patented because of the expense (Rampersad, Quester, \& Troshani, 2009). As a more holistic indicator of commercialisation outcomes, Harmon et al. (1997) argue that the number of new products and services is a more suitable measure for output from innovation networks. However, that measure captures outcomes mainly from a firm's perspective rather than the range of network players. Similarly, other studies have adopted the perspective of a firm and examined measures of value creation, such as the number of innovations in the past three years (Tsai \& Ghoshal, 1998). Bozeman and Boardman (2014) observe that knowledge-based collaborations are commonly measured in terms of papers produced or cited, while property-based collaborations rely on patents, new technologies developed, start-up firms, and profits from new products. Others suggest measures from a broader perspective, although without empirical data. Narayanan et al. (2009) suggest outcomes for not-for-profit organisations that are quite vague, such as commercialisation related outcomes or efficiency. Outcomes for firms might be strategic benefits, which are hard to quantify in advance. For the university, outcomes may include new R\&D capability, new technology creation, knowledge diffusion or social benefit. Bozeman and Rogers (2002) also suggest a churn model of value creation associated with the uses of knowledge, based on a historical analysis of the Internet. Leven et al. (2013) identify potentially quantifiable outcomes from projects stemming from innovation networks (including research publications, new products, new companies, new installations and new jobs). Given varied interests, the European Commission therefore calls for more research around a participatory, multi-perspective approach for assessing outcomes that reflect the objectives of key stakeholders (Diez, 2001). This study will address these calls.

\section{Case Study - The Tonsley Innovation Cluster}

The study was based on a case study of the Tonsley innovation cluster. Given the exploratory nature of the research and the complexity of networks, a case study approach was deemed suitable. The case study approach is prevalent and justified in network research given the connected nature of networks (Iacobucci, 1996). Additionally, case studies are applicable as they are needed to explore the underlying NM processes under investigation. This approach was also selected as it provides the benefit of detailed capture of reality (Galliers, 1990).

The AUS $\$ 1.5$ billion Tonsley cluster is located in a site formerly housing a manufacturing centre for Mitsubishi in South Australia and is now one of industry renewal and investment by local, state and federal government. The departure of Mitsubishi and more recently, Holden from South Australia, involved a significant loss of jobs. Figure 1 is a network diagram of the Tonsley Innovation Cluster. 

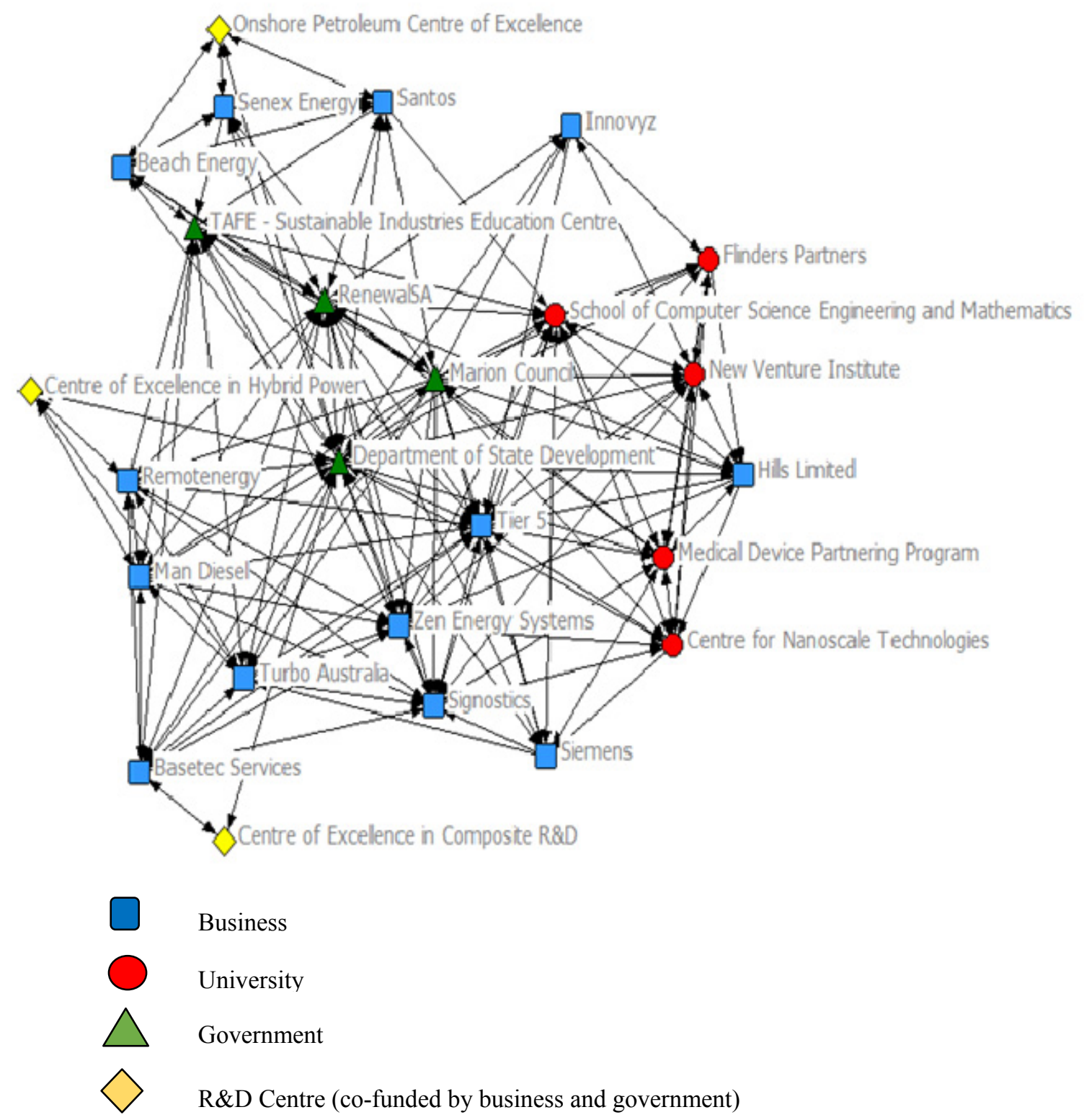

Figure 1. Network diagram of the Tonsley innovation cluster

Key government agencies include State government departments, such as the Department of State Development and RenewalSA as well as local government, the City of Marion. The State Government has also invested AUS\$125 million in developing the Sustainable Industries Education Centre for the training college, TAFE which was opened in 2014. Flinders University has also invested AUS \$120M in the development of that site and has housed its Computer Science, Engineering and Mathematics (CSEM) School there from January 2015. The co-location of such a School is a significant feature of this cluster given the track record of the School in university business collaboration including its successful contract R\&D program including the Medical Device Partnering Program (MDPP, 2015) and leading industry placement program for its students spanning over 2 decades. Another university contract R\&D nanotechnology group has also been co-located along with the University's New Venture Institute focused on entrepreneurial activities (NVI, 2015) and its commercialisation office, Flinders Partners from January 2015. Several businesses have relocated to Tonsley including Siemens, Tier 5, Zen Energy, Signostics, Hills 
Industries and Innovyz with more planned over the upcoming couple years. There are also a number of research and development (R\&D) Centres of Excellence, co-funded by mining and oil companies such as Bastec Services, Man Diesel, Turbo Australia, Remotenergy, Santos, Beach Energy and Senex Systems. Given the downturn of manufacturing in South Australia and nationally due to high labour costs and the high dollar, this redevelopment is seen as the State's response to the manufacturing crisis given the need to develop higher value, advanced products and services (Tonsley, 2015).

\section{Findings}

Figure 2 shows how the Tonsley case study addresses key factors in partnership formation, management and performance monitoring of the cluster. These will be discussed through this section.

\begin{tabular}{|c|c|c|}
\hline Partnership Formation & Network Orchestration & Network Outcomes \\
\hline $\begin{array}{l}\text { Determine cluster } \\
\text { specialisations }\end{array}$ & $\begin{array}{l}\text { Manage knowledge mobility } \\
\text { student projects; joint grants; } \\
\text { exchange programs. }\end{array}$ & $\begin{array}{l}\text { Government: return on } \\
\text { investment, employment, industry } \\
\text { attraction / development, capacity } \\
\text { building }\end{array}$ \\
\hline $\begin{array}{l}\text { Communicate existing } \\
\text { capabilities } \\
\text { website, social media, } \\
\text { meetings, expos, public } \\
\text { relations, networking } \\
\text { initiatives. }\end{array}$ & $\begin{array}{l}\text { Manage innovation } \\
\text { attribution } \\
\text { Agreements around contract } \\
\text { R\&D, intellectual property } \\
\text { management, licenses. }\end{array}$ & $\begin{array}{l}\text { Firm: sales, productivity, skilled } \\
\text { staff, new products/ services, } \\
\text { patents }\end{array}$ \\
\hline $\begin{array}{l}\text { Create value chains } \\
\text { Co-location of } \\
\text { engineering school R\&D } \\
\text { groups and firms }\end{array}$ & $\begin{array}{l}\text { Manage network stability } \\
\text { Build reputation }\end{array}$ & $\begin{array}{l}\text { University: Research: grant } \\
\text { income, publications, citations; } \\
\text { Teaching: graduate employability; } \\
\text { Commercialisation: R\&D contract } \\
\text { income, startups, patents }\end{array}$ \\
\hline
\end{tabular}

Figure 2. Conceptual framework for managing innovation clusters

\subsection{Partnership Formation}

The Tonsley case illustrates key processes in relationship formation within clusters such as determining of cluster specialisations, communicating existing capabilities and creating of value chains.

\subsubsection{Determine Cluster Specializations}

To focus efforts around the development of partnerships for Tonsley, key priority specialisations were identified, leveraging on the strengths of Tonsley and the priorities for South Australia including mining and resources, medical and assistive devices and environmental industries as outlined in government's manufacturing strategy, 'Manufacturing Works: A strategy for driving high-value manufacturing in South Australia' (DMITRE, 2012).

First, mining and resources includes a range of technologies, equipment, training, design and engineering services. A number of firms have been attracted to Tonsley that operate in the mining sector. For instance, Basetec Services has invested AUS\$9 million in forming a Centre of Excellence in composite pipeline technologies and the State government has co-invested \$1.5 million to establish the Centre of Excellence in Composites Research and Development at Tonsley. Additionally, MAN Diesel and Turbo Australia/Remotenergy have been engaged with the State Government to establish a Centre of Excellence in hybrid power development at Tonsley. Similarly, an Onshore Petroleum Centre of Excellence has been formed through investment by oil companies including Santos, Beach Energy and Senex Energy. 
Second, medical devices and assistive technologies has also been identified as a key area of specialisation. It will leverage on Flinders University strength in this area through its leading Medical Device Partnering Program (MDPP) that promotes collaboration and technology development of medical devices. It will also draw on the nearby Flinders Medical Centre and the co-location of the School of Computer Science Engineering and Mathematics, from which the MDPP is based. An international medical device manufacturer, Signostics has also relocated to Tonsley.

Third, clean technology has also been idnetified an important area of specialisation. This includes renewable energy, clean technologies such as water and transport technology, waste management, and green building design and construction materials. Firms such as ZEN Energy Systems have relocated its head office, R\&D, manufacturing and other major operations to Tonsley. International energy leader, Siemens has also located its maintenance and repair facility to Tonsley. The co-location of TAFE's Sustainable Industries Education Centre is also be well aligned to this specialisation given its focus on green construction and building products, materials and services, engineering, design, modelling and simulation. Similarly, Flinders University's Centre for Nanoscale Science and Technology also contributes to this specialisation given its expertise in clean technologies such as solar and water technologies. Global technology giant Siemens, is also co-located at Tonsley to service its energy technology business.

\subsubsection{Communicate Existing Capabilities}

The Tonsley pilot involves a number of mechanisms for communication of capabilities of each partner.

First online presence through websites and social media have been used. In addition to official Tonsley websites by the State government, Flinders University, TAFE, there are also websites articulating capabilities within the CSEM school, MDPP and the Centre for Nanoscale Science and Technology, and social media for instance through the NVI. In addition, there are a number of exhibitions such as CSEM's student expo and the MDPP networking events to showcase the capabilities and to inspire future collaborative projects. Additionally, a number of public relations events at Tonsley tapping into the reach of the local government council, the City of Marion, by inviting all local constituents to raise the profile and awareness about the cluster.

Furthermore, the State Government has also planned a number of networking/ educational initiatives help participants to imagine future pathways and to express areas of existing capabilities and future needs. One such initiative is the Manufacturing Leaders Network which will include experienced executives to engage with each other and focus on thinking about value chains, innovation and strategy. Another initiative is the High Performance Workplaces to foster linkages between government and industry to build future models and workplaces. (DMITRE, 2012)

\subsubsection{Create Value Chains}

Value chains can be created at Tonsley through the co-location of R\&D skilled groups from Flinders University, TAFE and industry partners.

Furthermore, the State government has a number of initiatives to promote value chains in identified areas of the mining, resource and energy. For instance, a Mining Industry Participation Office (MIPO) will be established to liaise with members of the mining industry and research providers to build local capability, identify service and technology needs by the mining industry, determine existing and future capabilities, align workforce development strategies and establish centres of excellence in relevant areas such as simulation and modelling. Additionally, a PACE Manufacturing program will be created to boost industry awareness about supply requirements for the mining sector, standards, levels of compliance, benchmarking and overall development of capability. (DMITRE, 2012)

\subsection{Network Management / Orchestration}

The Tonsley case sheds light on a number of management processes including the management of knowledge mobility, innovation appropriability and network stability.

\subsubsection{Manage Knowledge Mobility}

Processes and programs have been established to facilitate knowledge mobility by the university and government involving a range of stakeholders from university including both students and staff as well as industry.

On the student level, at Flinders University, work integrated learning (WIL) is an embedded component of most courses. WIL involves student projects with industry and can take several forms such as placements, capstone consulting projects and design projects. The New Venture Institute is instrumental in facilitating such student projects with industry.

At the level of the university researcher, participation in a number of industry grant programs are important to 
mobilise knowledge transfer. Such grants can be federally funded for instance, the Australian Research Council linkage grants requiring co-investment by firms, university and the federal government. Additionally, the innovation voucher program managed by the Department of State Development has been established to connect manufacturers with research providers to develop solutions to commercial problems. Furthermore, the State Government has also established a Reciprocal Exchange between Industry and Academics Program to facilitate the transfer of academics to the workplace to work on industry problems. (DMITRE, 2012)

\subsubsection{Manage Innovation Appropriability}

To manage intellectual property involving the university, the university's commercialization office, Flinders Partners (FP) has been located at Tonsley. FP has expertise in developing agreements around contract R\&D, patents, licenses and confidentiality agreements.

\subsubsection{Manage Network Stability}

To manage network stability the university and state government have focused on reputation, profile, inspiration and building an innovation culture.

On the university level, the NVI runs Venture Dorm, a Start up program and winner of the Business/Higher Education Round Table (B/Hert) Award for Best Entrepreneurial Education of the Year. It focuses on supporting entrepreneurs in developing their ideas through industry mentorship, legal and technology consulting support. The NVI also run the Entrepreneurs in Conversation Series which involves high-profile entrepreneurs to share their stories to inspire and boost an innovative culture (NVI, 2015).

On the government level, an Innovation in Management Education Program will be developed for South Australian universities and other private education and training facilities. The government will also establish the STEM portal to promote study and career opportunities in science, technology, engineering to position the sector as attractive and to foster skill and career development. (DMITRE, 2012)

\subsection{Network Outcomes / Performance Management}

Performance metrics for the Tonsley project have been defined by State government. For government, a number of metrics have been identified pertaining to return on investment (gross state product, labour productivity, infrastructure of use to community), employment targets (jobs from existing and startup firms, wage rate growing with productivity, improved capabilities), industry attraction and development (value of output, value of import substitution, value of exports, patent registrations), and capacity building (strategic alliances across value chains and clusters). For business, target outcomes include sales, productivity, patents, employment of skilled staff (entrepreneurship, ambition, capability /appropriate skills/ command of critical knowledge domains, experience, continuous improvement, mutual responsibility and loyalty, low turnover) and the development of new products and services (global niche market, interlinked product-service solutions, well-defined continuous and integrated innovation, reputation for high-quality innovative products and services). On the university level, the government has outlined metrics of a 'comprehensive, integrated approach to innovation and strategic alliances across value chains and clusters'. (DMITRE, 2012, pp. 61-62)

Furthermore, delving deeper into university performance metrics, three key areas are generally rewarded including research (grant income for instance through ARC linkage grants and innovation vouchers, publications and citations), teaching (graduate employability through WIL and the course evaluation questionnaire which students complete at the end of their course); and commercialisation ( $R \& D$ contract income, patents and start-ups).

\section{Managerial Implications}

This study has pertinent managerial implications as economies transition towards higher value-add industries. It will be useful to government departments pertaining to manufacturing, innovation, industry, science, economic development, education and skills development in cluster policy development and in facilitating goals focused on industry attraction and development, employment targets and up skilling, and the building of a high-value innovation economy. In particular, the study is valuable for government departments with responsibility for economic development and urban renewal. It will assist them in policy development around governance of innovation precincts, as they attempt to boost transformation from traditional manufacturing towards the development of high value-add industries, products and services. It offers a useful framework for managing innovation clusters that would be beneficial in the effective governance of such initiatives. This framework can be used for analyzing dynamics and evaluating performance as clusters evolve. Overall, it resonates with the global trend towards growing advanced manufacturing and consequently, the findings of this study can be integrated into government policies on how best to 
support innovation through effective cluster management.

Additionally, the study is also valuable for firms. First, as it informs policy development around cluster development, it will strengthen frameworks for research and development (R\&D) collaboration. Effective collaboration with educators or R\&D partners benefits firms. It will allow managers within firms to build stronger relationships with like-minded organizations. Second, success of an innovation precinct is important in attracting future tenants, thereby increasing business partnership opportunities for participating firms. Indeed, such benefits of attraction of new partners and the viability of existing cluster partners are useful for business partnering opportunities and hence for relationship marketers. In essence, the project will assist firms within the innovation precinct in building collaborations and realising value from their relocation to the precinct. This would contribute to effective governance surrounding the cluster and in turn the identity, positioning and branding of the cluster; synergies for participating firms; and future attraction of additional firms and hence, prospective partners for participating firms.

It also has insights for managing innovation networks on a broader level such as cooperative research centres or university-industry collaboration in unpacking key issues in forming and managing underlying partnerships and articulating meaningful performance metrics.

Furthermore, it offers implications for universities in their marketing, industry engagement strategies, regional innovation and their developing their strategic positioning as the key contributors of innovative skills for the high-value technological economy.

\section{Conclusion}

Innovation clusters have experienced high failure rates due to inadequate development of underlying relationships between firms and the ineffective performance monitoring towards outcomes of value to the range of stakeholders. Based on the live Australian pilot study of the Tonsley innovation cluster, this paper contributes theoretically by extending network management theory. The study contributes to our understanding of important elements in the formation of innovation clusters and its underlying networks; the management and orchestration of key stakeholders; and the performance monitoring towards achievement of anticipated outcomes. Unlike past studies that have been predominantly based on the perspective on one main stakeholder, it draws on multiple perspectives in developing a useful performance monitoring framework for innovation clusters.

Despite its benefits, the study has limitations and therefore it paves the way for future research. First, it is based on a single case study and therefore future research can compare and contrast it to other innovation clusters in other industries, specialisations, states and countries to identify patterns and benchmark performance. Nevertheless, this case study was deemed suitable as it included several cluster specialisations including mining and energy, medical devices, clean technology and green buildings. Second, as this particular innovation cluster evolves and more tenants are attracted to the site with more collaborations being fostered, value networks within each specialisation can be examined deeply and trends identified to strengthen theory developing in the management of innovation clusters. Third, a quantitative model should be developed to monitor cluster dynamics and performance to determine whether it is on track or whether corrective action should be taken. Fourth, as the innovation cluster matures, a longitudinal study can be undertaken to investigate the evolution of the cluster and value chains in various phases so that relevant management strategies can be applied in each phase in the development of future innovation clusters.

Indeed, this pilot is instrumental in paving the way for the effective management of innovation clusters in the future.

\section{References}

Ács, Z. J., Autio, E., \& Szerb, L. (2014). National Systems of Entrepreneurship: Measurement issuesand policy implications. Research Policy, 43(3), 476-494. http://dx.doi.org/10.1016/j.respol.2013.08.016

Antcliff, M., \& Kumic, I. (2013). Renewing Tonsley, Regenerating Adelaide - The making of Australia's most competitive city. Paper presented at the State of Australian Cities Conference.

Bercovitz, J., \& Feldman, M. (2011). The mechanisms of collaboration in inventive teams: Composition, social networks, and geography. Research Policy, 40(1), 81-93. http://dx.doi.org/10.1016/j.respol.2010.09.008

Boggs, J. S., \& Rantisi, N. M. (2003). The 'relational turn' in economic geography. Journal of Economic Geography, 3(2), 109-116. http://dx.doi.org/10.1093/jeg/3.2.109

Boschma, R. (2005). Proximity and innovation: a critical assessment. Regional Studies, 39(1), 61-74. http://dx.doi.org/10.1080/0034340052000320887

Bozeman, B., \& Boardman, C. (2014). Research Collaboration and Team Science: A State-of-the-Art Review and 
Agenda. Springer.

Bozeman, B., \& Rogers, J. D. (2002). A churn model of scientific knowledge value: Internet researchers as a knowledge value collective. Research Policy, 31, 769-794. http://dx.doi.org/10.1016/S0048-7333(01)00146-9

Cantù, C. (2010). Exploring the role of spatial relationships to transform knowledge in a business idea -- Beyond a geographic proximity. Industrial Marketing Management, 39(6), 887-897. http://dx.doi.org/10.1016/j.indmarman.2010.06.008

Chyi, Y. L., Lai, Y. M., \& Liu, W. H. (2013). Knowledge spillovers and firm performance in the high-technology industrial cluster. Research Policy, 41(3), 556-564. http://dx.doi.org/10.1016/j.respol.2011.12.010

Clarysse, B., Wright, M., Brunnel, J., \& Mahajan, A. (2014). Creating value in ecosystems: Crossing the chasm between knowledge and business ecosystems. Research Policy, 43(1164-1176). http://dx.doi.org/10.1016/j.respol.2014.04.014

Corsaro, D., Cantù, C., \& Tunisini, A. (2012). Actors' heterogeneity in innovation networks. Industrial Marketing Management, 41(5), 780-789. http://dx.doi.org/10.1016/j.indmarman.2012.06.005

Cowan, R., \& Zinovyeva, N. (2013). University effects on regional innovation. Research Policy, 42(3), 788-800. http://dx.doi.org/10.1016/j.respol.2012.10.001

Cumming, D. J., \& MacIntosh, J. G. (2006). Crowding out private equity: Canadian evidence. Journal of Business Venturing, 21(5), 569-609. http://dx.doi.org/10.1016/j.jbusvent.2005.06.002

Dhanaraj, C., \& Parkhe, A. (2006). Orchestrating innovation networks. Academy of Management, 31(3), 659-669. http://dx.doi.org/10.5465/AMR.2006.21318923

Dicken, P., \& Malmberg, A. (2001). Firms in territories: a relational perspective. Economic Geography, 77(4), 345-363. http://dx.doi.org/10.1111/j.1944-8287.2001.tb00169.x

Diez, M. A. (2001). The evaluation of regional innovation and cluster policies: Towards a participatory approach. European Planning Studies, 9(7), 907-923. http://dx.doi.org/10.1080/09654310120079832

DMITRE. (2012). Manufacturing Works: A strategy for driving high-value manufacturing in South Australia. Department for Manufacturing, Innovation, Trade, Resources and Energy (DMITRE), Government of South Australia.

Ford, D., Håkansson, H., Snehota, I., \& Gadde, L. E. (2002). Managing Networks. Paper presented at the Proceeding of the 18th IMP Conference, Perth, Australia.

Fradley, K., Troshani, I., Rampersad, G. C., \& De Ionno, P. (2012). An Organizing Vision Perspective on Green IS Development. Proceedings from the International Conference on Information Systems (ICIS), Orlando, USA.

Freeman, C. (1995). The 'National Systems of Innovation' in historial perspective. Cambridge Journal of Economics, 19, 5-24.

Galliers, R. D. (1990). Choosing appropriate information systems research approaches: a revised taxonomy. In H.-E. Nissen, H. K. Klein \& R. Hirscheheim (Eds.), The Information Systems Research Arena of the 90's, Perceptions and Alternative Approaches (pp. 155-173). Copenhagen.

Garrett-Jones, S., Turpin, T., Burns, P., \& Diment, K. (2005). Common purpose and divided loyalties: the risks and rewards of cross-sector collaboration for academic and government researchers. $R \& D$ Management, 35(5), 535-544. http://dx.doi.org/10.1111/j.1467-9310.2005.00410.x

Garrett-Jones, S. (2004). From citadels to clusters: the evolution of regional innovation policies in Australia. $R \& D$ Management, 34(1), 3-16. http://dx.doi.org/10.1111/j.1467-9310.2004.00318.x

Giuliani, E. (2013). Network dynamics in regional clusters; Evidence from Chile. Research Policy, 42(8), 1406-1419. http://dx.doi.org/10.1016/j.respol.2013.04.002

Hakansson, H. (1982). International Marketing and Purchasing of Industrial Goods: An Interaction Approach. Chichester: Wiley., Chichester; New York; Brisbane; Toronto; Singapore.

Harmon, B., Ardishvili, A., Cardozo, R., Elder, T., Leuthold, J., Parshall, J., . . . Smith, D. (1997). Mapping the University Technology Transfer Process. Journal of Business Venturing, 12, 423-434. http://dx.doi.org/10.1016/S0883-9026(96)00064-X

Iacobucci, D. (1996). Networks in Marketing. Sage Publications, California, London, New Delhi. 
Iammarino, S., \& McCann, P. (2006). The structure and evolution of industrial clusters: Transactions, technology and knowledge spillovers. Research Policy, 35(7), 1018-1036. http://dx.doi.org/10.1016/j.respol.2006.05.004

Isaksen, A., \& Hauge, E. (2002). Regional Clusters in Europe. Observatory of European SMEs report. European Communities. Luxembourg

Jacobides, M. G., Knudsen, T., \& Augier, M. (2006). Benifiting from innovation: Value creation, value appropriation and the role of industry architectures. Research Policy, 35, 1200-1221. http://dx.doi.org/10.1016/j.respol.2006.09.005

Leven, P., Holmstrom, J., \& Mathiassen, L. (2013). Managing research and innovation networks: Evidence from a government sponsored cross-industry program. Research Policy, 43(1), 156-168. http://dx.doi.org/10.1016/j.respol.2013.08.004

Leydesdorff, L., \& Etzkowitz, H. (1996). Emergence of a Triple Helix of university-industry-government relations. Science and public policy, 23(5), 279-286. http://dx.doi.org/10.1093/spp/23.5.279

Manning, S. (2013). New Silicon Valleys or a new species? Commoditization of knowledge work and the rise of knowledge services clusters. Research Policy, 42(2), 379-390. http://dx.doi.org/10.1016/j.respol.2012.06.011

Marshall, A. (1920). Principles of Economics. Macmillan, London.

Massey, D., Qintas, P., \& Wield, D. (2004). High-tech fantasies: Science parks in society, science and space. Routledge, London.

MDPP. (2015). Medical Device Partnering Program. Retrieved February 6, 2015, from $\mathrm{http}: / /$ www.flinders.edu.au/mdpp/

Möller, K. K., \& Rajala, A. (2007). Rise of strategic nets - new modes of value creation. Industrial Marketing Management, 36(7), 895-908. http://dx.doi.org/10.1016/j.indmarman.2007.05.016

Narayanan, V. K., Yang, Y., \& Zahra, S. A. (2009). Corporate venturing and value creation: A review and proposed framework. Research Policy, 38, 58-76. http://dx.doi.org/10.1016/j.respol.2008.08.015

Nicholson, J., Tsagdis, D., \& Brennan, R. (2013). The structuration of relational space: Implications for firm and regional competitiveness. Industrial Marketing Management, 42(3), 372-381. http://dx.doi.org/10.1016/j.indmarman.2013.02.013

NVI. (2015). New Venture Institute. Retrieved February 10, 2015, from http://nviflinders.com.au/

Patel, F., Sooknanan, P., Rampersad, G., \& Munkkur, A. (2012). Information technology, development and social change. Routledge.

Perkmann, M., Tartari, V., McKelvey, M., Autio, E., Brostrom, P. E., Fini, R., . . S Sobrero, M. (2013). Academic engagement and commercialisation: A review of the literature on university-industry relations. Research Policy, 42, 423-442. http://dx.doi.org/10.1016/j.respol.2012.09.007

Rampersad, G. C. (2015). Developing university-business cooperation through work-integrated learning. International Journal of Technology Management, 68(3-4), 203-227. http://dx.doi.org/10.1504/IJTM.2015.069664

Rampersad, G. C., Quester, P., \& Troshani, I. (2010a). Examining network factors : commitment, trust, coordination and harmony. Journal of Business and Industrial Marketing, 25(7), 487-500. http://dx.doi.org/10.1108/08858621011077727

Rampersad, G. C., Quester, P., \& Troshani, I. (2010b). Managing innovation networks: Exploratory evidence from ICT, biotechnology and nanotechnology networks. Industrial Marketing Management, 39(5), 793-805. http://dx.doi.org/10.1016/j.indmarman.2009.07.002

Rampersad, G., \& Troshani, I. (2013). High-speed broadband: assessing its social impact. Industrial Management \& Data Systems, 113(4), 541-557. http://dx.doi.org/10.1108/02635571311322784

Rampersad, G., Quester, P., \& Troshani, I. (2009). Developing and evaluating scales to assess innovation networks. International Journal of Technology Intelligence and Planning, 5(4), 402-420. http://dx.doi.org/10.1504/IJTIP.2009.029378

Rampersad, G., Troshani, I., \& Plewa, C. (2012). IOS adoption in innovation networks: a case study. Industrial Management \& Data Systems, 112(9), 1366-1382. http://dx.doi.org/10.1108/02635571211278974 
Saxenian, A. (1994). Regional Advantage. Culture and Competition in Silicon Valley and Route 128. Harvard University Press, Cambridge.

Sorenson, O., Rivkin, J. W., \& Fleming, L. (2006). Complexity, networks and knowedge flow. Research Policy, 35, 994-1017. http://dx.doi.org/10.1016/j.respol.2006.05.002

Tallman, S., \& Phene, A. (2007). Leveraging knowledge across geographic boundaries. Organization Science, 18(2), 252-260. http://dx.doi.org/10.1287/orsc.1060.0227

Teece, D. J. (1986). Profiting from technological innovation: implications for integration, collaboration, licensing and public policy. Research Policy, 15, 285-305. http://dx.doi.org/10.1016/0048-7333(86)90027-2

Tonsley. (2015). Tonsley innovation precinct. Retrieved February 10, 2015, from http://www.tonsley.com/

Tsai, W., \& Ghoshal, S. (1998). Social capital and value creation: the role of intrafirm networks. Academy of Management Journal, 41(4), 464-478. http://dx.doi.org/10.2307/257085

Turpin, T., \& Garrett-Jones, S. (1997). Innovation networks in Australia and China. In H. Etzowitz \& L. Leydesdorff (Eds.), Universities and the Global Knowledge Economy: A Triple Helix of University-Industry-Government Relations. Pinter, London.

WEForum. (2014). World Economic Forum, Global Competitiveness Report 2013-2014. Retrieved June 19, from www.weforum.org

Wilkinson, I., Ritter, T., \& Johnston, W. (2004). Managing in Business Networks. Industrial Marketing Management, 33(3), 175-183. http://dx.doi.org/10.1016/j.indmarman.2003.10.016 